\title{
KARKAS AYAM BURAS YANG DIBERI RANSUM MENGANDUNG SUSU KADALUARSA
}

\author{
NURIYASA, I. M., M. E. D., PERTIWI, A. W. PUGER, DAN E. PUSPANI \\ Fakultas Peternakan, Universitas Udayana \\ e-mail: madenuriyasa@unud.ac.id
}

\begin{abstract}
ABSTRAK
Penelitian ini bertujuan untuk mengetahui pengaruh penggantian tepung ikan dengan susu kadaluarsa dalam ransum terhadap karkas ayam buras. Rancangan percobaan yang digunakan dalam penelitian ini adalah Rancangan Acak Lengkap (RAL), dengan lima perlakuan dan lima ulangan, setiap unit percobaan terdiri dari empat ekor ayam buras jantan. Perlakuan adalah ransum tanpa penggantian tepung ikan (Ro); ransum pengantian 25\% tepung ikan dengan susu kadaluarsa (R1); ransum pengantian 50\% tepung ikan dengan susu kadaluarsa (R2); ransum pengantian $75 \%$ tepung ikan dengan susu kadaluarsa (R3) dan ransum pengantian 100\% tepung ikan dengan susu kadaluarsa (R4). Ransum dan air minum diberikan secara ad libitum. Variabel yang diamati adalah karkas dan komposisi fisik karkas. Hasil penelitian mendapatkan berat karkas dan berat daging perlakuan R3 lebih tinggi $(\mathrm{P}<0,05)$ dibandingkan R4, R2, R1 dan Ro. Semua perlakuan tidak berpengaruh nyata $(\mathrm{P}>0,05)$ terhadap potongan komersial karkas. Penelitian menyimpulkan bahwa penggantian tepung ikan dengan susu kadaluarsa pada aras 75\% menghasilkan karkas lebih tinggi dibandingkan perlakuan lain.
\end{abstract}

Kata kunci: tepung ikan, susu kadaluarsa, karkas

\section{CARCASS OF NATIVE CHICKEN DUE TO FEEDING CONTAINS EXPIRED MILK}

\begin{abstract}
This study aims to determine the effect of replacing fish meal with expired milk in rations on native chicken carcass. The experimental design used in this study was a completely randomized design (CRD), with five treatments and five replications, each experimental unit consisting of four male native chickens. The treatments were ration without replacement of fish meal (Ro); ration replacement of $25 \%$ fish meal with expired milk (R1); ration for $50 \%$ replacement of fish meal with expired (R2); ration for replacement of $75 \%$ fish meal with expired milk (R3) and ration for replacing $100 \%$ fish meal with expired milk (R4). Rations and water were given ad libitum. The variables observed were carcass and carcass physical composition. The results showed that carcass weight and meat weight of treatment $\mathrm{R} 3$ were higher $(\mathrm{P}<0.05)$ than $\mathrm{R} 4, \mathrm{R} 2, \mathrm{R} 1$ and Ro. All treatments had no significant different $(\mathrm{P}>0.05)$ on the commercial carcass. The study concluded that replacing fish meal with expired milk at the level of $75 \%$ resulted in higher carcass than other treatments.
\end{abstract}

Key words: fish meal, expired milk, native chicken, native chicken carcass

\section{PENDAHULUAN}

Ayam buras memiliki keunggulan yaitu relatif lebih tahan terhadap penyakit dibandingkan ayam ras, pemelihraan lebih gampang, diberi makan pagi hari saat akan dilepas berupa sisa-sisa makanan dan tambahan bekatul secukupnya selebihnya ayam dianggap dapat mencari makan sendiri disekitar rumah. Daging dan telur ayam buras juga sangat diminati dan mampu memenuhi kebutuhan protein hewani masyarakat
(Anwar, 2011). Ayam buras juga merupakan sektor strategis dalam meningkatkan nilai gizi masyarakat, pemenuhan pangan dan berpotensi meningkatkan pendapatan peternak di Indonesia (Pusdatin, 2015).

Di daerah pedesaan, ayam buras biasanya dipelihara secara ekstensif sehingga terdapat beberapa permasalahan yang diantaranya; (i) tingkat reproduksinya rendah, karena tingkat kematian pada anak ayam relatif lebih tinggi; (ii) kendali akan keberadaan ayam kurang, sehingga kemungkingan dimangsa predator maupun 
hilang lebih tinggi. Pemeliharaan secara intensif, dapat mengurangi kendala tersebut, tetapi persoalan harga pakan tinggi dan bahan pakan yang harganya sering berfluktuatif dan sulit didapat (Anwar, 2011).

Susu afkir adalah salah satu bahan ayam buras yang belum banyak digali potensinya. Kandungan nutrient pada susu afkir adalah: protein kasar 25,8 \%, lemak 0,9 $\%$, laktosa 4,6\%. Susu afkir mengandung nutrient mikro pada susu afkir sangat komplit, seperti vitamin, mineral dan asam amino. Vitamin yang terdapat di dalam lemak susu yaitu vitamin A, D, E, K, sedangkan vitamin yang larut di dalam susu yaitu vitamin B kompleks, vitamin $\mathrm{C}$, vitamin $\mathrm{A}$ dan vitamin $\mathrm{D}$ (Widodo, 2002). Vitamin yang larut di dalam susu yang terpenting ialah vitamin B1, B2, asam nikotinat, dan asam pantotenat (vitamin B5). Mineral yang terkandung dalam susu adalah kalsium, magnesium, fosfor (Poedjiadi, 2006). Yadnya et al (2019) menyatakan kualitas ransum akan berpengaruh terhadap berat potong dan berat karkas itik. Menurut Pertiwi (2016) susu afkir mengandung energi termetabolis $3023,12 \mathrm{kkal} / \mathrm{kg}$, protein $13,57 \%$, kalsium 1,83\%, posfor 0,13\%, lemak kasar 18,63\% dan serat kasar 6,29\%. Hasil penelitian Alim et al. (2012) mendapatkan bahwa penambahan susu afkir sebesar $5 \%, 7.5 \%$, dan $10 \%$ dari total ransum memberikan bobot yang semakin tinggi dibandingkan ransum komersial tanpa penambahan susu afkir. Penambahan susu afkir sebesar 10\% dari total ransum memberikan hasil terbaik terhadap peningkatan konsumsi pakan broiler.

Tepung ikan adalah bagian dari ikan yang minyaknya diambil atau tidak, dikeringkan kemudian digiling. Tepung ikan sebagai bahan baku pabrik pakan mempunyai kualitas yang beragam, tergantung dari jenis ikan dan asal tepung ikan brkisar $50-60 \%$ (SNI, 1996). Nuriyasa et al. (2014) mendapatkan bahwa tepung ikan produksi lokal mengandung protein $39 \%$.

Peternak sering mengalami persoalan harga ransum dari hari ke hari semakin mahal, sedangkan kualitas dari bahan pakan yang ada semakin menurun. Ketersedian tepung ikan sering mengalami kendala karena bersaing dengan ternak lain, dan harga sangat berfluktuatif. Kondisi yang serba sulit seperti itu peternak dituntut agar mampu memanfaatkan limah agroindustri (susu kadaluarsa) yang kaya nutrien sehingga diharapkan dapat meningkatkan pertumbuhan ayam buras dan meningkatkan produksi karkas.

\section{MATERI DAN METODE}

\section{Ternak dan rancangan percobaan}

Seratus ekor ayam buras yang berumur 2 minggu digunakan dalam percobaan rancangan acak lengkap (RAL). Berat badan ayam yang digunakan dalam penelitian mempunyai berat homogen $(173 \pm 5,19 \mathrm{~g})$.

\section{Ransum percobaan}

Ransum diformulasi sesuai dengan kebutuhan ayam buras umur 2-10 minggu (Scott et al., 1982). Ransum disusun dari bahan jagung kuning, bungkil kelapa, tepung ikan, susu kadaluarsa (bubuk), kedelai, dedak padi, minyak kelapa, $\mathrm{NaCl}$, dan mineral mix.Formulasi ransum dan kandungan nutrient ransum disajikan pada Tabel 1 dan Tabel 2.

\section{Kandang percobaan}

Kandang percobaan merupakan kandang system batteray terdiri dari 25 petak, masing-masing petak berukuran panjang $80 \mathrm{~cm}$, lebar $50 \mathrm{~cm}$ dan tinggi $75 \mathrm{~cm}$. Tiap petak kandang diisi 4 ekor ayam buras jantan. Kandang terbuat dari pilah-pilah bambu dan tersekat bambu pada masing-masing petak dan tiap petak kandang sudah dilengkapi dengan tempat pakan dan air yang terbuat dari bambu. Pada bagian bawah kandang diberi lapisan plastik untuk menampung sisasisa pakan yang jatuh

Tabel 1. Komposisi penyususn ransum ayam buras umur $2-10$ minggu

\begin{tabular}{lccccc}
\hline \multirow{2}{*}{ Bahan } & \multicolumn{5}{c}{ Perlakuan } \\
\cline { 2 - 6 } & $\mathrm{R} 0$ & $\mathrm{R} 1$ & $\mathrm{R} 2$ & $\mathrm{R} 3$ & $\mathrm{R} 4$ \\
\hline Jagung Kuning & 55,00 & 54,18 & 54,30 & 54,00 & 50,25 \\
Bungkil Kelapa & 12,20 & 12,40 & 12,00 & 13,00 & 13,00 \\
Tepung Ikan & 10,00 & 7,50 & 5,00 & 2,50 & 0,00 \\
Susu Kadaluarsa & 0,00 & 2,50 & 5,00 & 7,50 & 10,00 \\
Kedelai & 6,70 & 10,92 & 14,55 & 18,25 & 22,10 \\
Dedak Padi & 14,05 & 10,25 & 6,70 & 2,10 & 1,60 \\
Minyak Kelapa & 1,40 & 1,60 & 1,80 & 2,00 & 2,40 \\
NaCl & 0,25 & 0,25 & 0,25 & 0,25 & 0,25 \\
Mineral Mix & 0,40 & 0,40 & 0,40 & 0,40 & 0,40 \\
\hline Total & 100 & 100 & 100 & 100 & 100 \\
\hline
\end{tabular}

Tabel 2. Kandungan nutrien ransum ayam buras umur 2-10 minggu

\begin{tabular}{lcccccc}
\hline & R0 & R1 & R2 & R3 & R4 & Standar \\
\hline ME (kkal/Kg) & 2908,97 & 2917,04 & 2930,93 & 2937,56 & 2901,82 & 2900 \\
Protein (\%) & 18,02 & 18,14 & 18,02 & 18,06 & 18,14 & 18,00 \\
Kalsium (\%) & 1,07 & 1,02 & 0,97 & 0,92 & 0,84 & 0,80 \\
Phosphor(\%) & 0,53 & 0,47 & 0,40 & 0,34 & 0,26 & 0,40 \\
Lemak (\%) & 7,20 & 8,00 & 8,75 & 9,39 & 10,64 & $5-82)$ \\
Serat Kasar (\%) & 5,05 & 4,95 & 4,78 & 4,69 & 4,78 & $3-82)$ \\
Lisin (\%) & 0,98 & 0,92 & 0,85 & 0,78 & 0,73 & 0,85 \\
Metionin (\%) & 0,39 & 0,35 & 0,32 & 0,28 & 0,25 & 0,30 \\
Sistin (\%) & 0,33 & 0,32 & 0,30 & 0,29 & 0,28 & 0,40
\end{tabular}

Standar Scott et al. (1982)

\section{Prosedur penelitian}

Sanitasi kandang dan bangunan kandang dibersihkan dan melakukan penyemprotan desinfektan. Ayam buras umur satu hari hingga satu minggu diberikan pakan komersial 511, setelah umur satu minggu dilakukan penyesuaian ransum perlakuan dengan cara mencampur ransum komersial dengan ransum perlakuan. Setalah 
umur dua minggu dilakukan pengacakan ayam dan diberikan ransum perlakuan. Pencampuran bahan pakan ransum dilakukan secara manual yaitu mencampur aduk bahan pakan menggunakan wadah dan diaduk menggunakan tangan. Pencampuran bahan pakan dilaksanakan setiap seminggu sekali. Masingmasing bahan pakan ditimbang sesuai perlakuan, penimbangan dimulai dari bahan yang proporsinya lebih besar. Bahan yang telah ditimbang kemudian dicampur dengan baik agar terbentuk ransum yang campurannya homogen.

Pemotongan ayam dilakukan dengan prosedur memotong vena yugularis pada leher untuk mengeluarkan darahnya (Alhaidary et al., 2010). Karkas ayam buras adalah daging bersama tulang hasil pemotongan, tanpa darah, setelah dipisahkan dari kepala sampai batas pangkal leher dan dari kaki sampai batas lutut serta dari isi rongga perut ayam. Badan Standardisasi Nasional (2009) menjelaskan karkas ayam pedaging adalah bagian tubuh ternak hidup setelah dikurangi bulu, dikeluarkan darah, jeroan, dan lemak abdominalnya, dipotong kepala dan leher serta kedua kakinya (ceker). Potongan komersial karkas didapatkan dengan mimisahkan bagian dada, sayap, paha atas, paha bawah, pinggang dan punggung. Karkas ayam buras terdiri dari bagian, yaitu dua buah sayap, satu bagian dada, satu bagian punggung dan dua bagian paha yang terdiri dari dua bagian thigh dan dua bagian drumstick. Komposisi fisik karkas didapat dengan cara memisahkan komponen tulang, lemak dan daging karkas.

\section{Analisis statistik}

Semua data dianalisis dengan ANOVA untuk menentukan perbedaan antara perlakuan pada selang kepercayaan $5 \%(\mathrm{P}<0,05)$. Jika perbedaan ditemukan, maka analisis lebih lanjut dilakukan dengan uji rentang ganda Duncan (Steel dan Torrie,1991).

\section{HASIL DAN PEMBAHASAN}

Perlakuan ransum $\mathrm{R}_{3}$ menghasilkan berat karkas ayam buras umur 10 minggu yaitu $836 \mathrm{~g}$ (Tabel 3). Perlakuan ransum Ro, R1, R2 dan R4 masing-masing 23,36\%; 19,89\%; 20,45\% dan 22,10\% nyata lebih rendah $(\mathrm{P}<0,05)$ dari perlakuan $\mathrm{R} 3$. Hal tersebut disebabkan karena ayam buras yang diberikan perlakuan $\mathrm{R} 3$ adalah perlakuan ransum yang mengandung $75 \%$ susu kadaluarsa dan 25\% tepung ikan. Komposisi ransum seperti ini mengandung tepung ikan zat nutrisi mikro yang terkandung saling melengkapi, sehingga asupan nutrisi yang masuk ke dalam tubuh cukup yang berdampak pada peningkatan berat badan. Harper et al. (1980) menyatakan ransum yang mengandung protein tinggi dan diikuti dengan konsumsi ransum tinggi menyebabkan retensi asam-asam amino dalam jaringan bertambah banyak sehingga pertumbuhan menjadi lebih baik dan menghasilkan produksi karkas yang maksimal.

Persentase karkas ayam buras yang mendapat perlakuan ransum R1 yaitu 66,47\%. Perlakuan R1, R2, R3 dan R4 masing-masing 2,33\%; 0,41\%; 0,48\% dan $2,36 \%$ lebih rendah $(\mathrm{P}>0,05)$ dari perlakuan R1. Hasil yang tidak berbeda nyata $(\mathrm{P}>0,05)$ dalam penelitian ini disebabkan karena berhubungan erat dengan berat potong yang tidak berbeda nyata. Sesuai dengan pendapat Wahju (2015) menyatakan bahwa produksi karkas erat hubunganya dengan bobot hidup. Hasil penelitian mendapatkan berat recahan karkas $(\mathrm{g} / 100 \mathrm{~g}$ karkas) yang meliputi: berat dada, punggung dan sayap, namun berpengaruh terhadap berat paha atas dan paha bawah. Hasil penelitian menunjukkan bahwa berat dada ayam buras yang paling tinggi pada perlakuan $\mathrm{R}_{3}$ yaitu 30,15\%. Ayam buras yang mendapat perlakuan Ro, R1, R2 dan R4 masing-masing 16,68\%; 12,80\%; $6,20 \%$ dan $2,72 \%$ lebih rendah tidak berbeda nyata $(\mathrm{P}>0,05)$ dari perlakuan $\mathrm{R} 3$. Hasil penelitian Nita et al. (2015) mendapatkan bahwa rataan berat dada ayam jantan petelur adalah 19,3 g/100 g karkas. Perbedaan hasil ini, disebabkan karena perbedaan strain ayam yang digunakan. Rataan persentase punggung ayam buras yang paling tinggi pada perlakuan Ro yaitu 26,05 g/10og karkas (Tabel 3 ). Ayam buras yang mendapat perlakuan R1, R2, R3 dan R4 masing-masing 6,64\%; 13,21\%; 18,43\% dan 11,44\% lebih rendah $(\mathrm{P}>0,05)$ dari perlakuan Ro. Persentase dada dari hasil penelitian lebih tinggi daripada penelitian Nita et al. (2015) disebabkan karena perbedaan jenis ayam yang dipakai dalam penelitian yaitu ayam petelur.

Rataan persentase punggung ayam buras dalam penelitian ini adalah 23,46 g/10og karkas. Persentase punggung menunjukkan tidak berbeda nyata $(\mathrm{P}>0,05)$ kemungkinan disebabkan karena komponen bagian punggung yang lebih didominasi oleh tulang sehingga tidak banyak terjadi perototan. Tulang merupakan organ berkembang paling awal dalam masa pertumbuhan dan merupakan komponen pembentuk struktur tubuh ayam buras sehingga perlakuan pakan tidak berpengaruh. Rose (1997) menyatakan bahwa faktor yang mempengaruhi pertumbuhan tulang adalah faktor genetik, sirkulasi hormon, kalsium, phosphor, vitamin A dan D. Menurut Mufti (2003), ayam buras jantan memiliki ukuran-ukuran tubuh lebih besar daripada ayam buras betina.

Tabel 3 menunjukkan bahwa persentase sayap ayam buras tidak menunjukkan berbeda nyata $(\mathrm{P}>0,05)$. Perlakuan ransum R1 menghasilkan persentase sayap 17,44 g/10og karkas. Perlakuan ransum Ro, R2, R3 dan R4 menghasilkan persentase sayap masing-masing 
Tabel 3. Karkas ayam buras jantan yang diberi perlakuan penggantian tepung ikan dengan susu kadaluarsa dalam ransum

\begin{tabular}{|c|c|c|c|c|c|c|}
\hline \multirow{2}{*}{ Variabel } & \multicolumn{5}{|c|}{ Perlakuan ${ }^{1)}$} & \multirow{2}{*}{$\mathrm{SEM}^{2)}$} \\
\hline & RO & R1 & R2 & R3 & R4 & \\
\hline Berat Karkas (g) & $640,75^{\mathrm{b} 3)}$ & $669,75^{b}$ & $665,00^{b}$ & $836,00^{a}$ & $651,25^{b}$ & 27,48 \\
\hline Persentase Karkas (\%) & $64,92^{\mathrm{a}}$ & $66,47^{\mathrm{a}}$ & $66,20^{\mathrm{a}}$ & $66,15^{\mathrm{a}}$ & $64,90^{\mathrm{a}}$ & 2,23 \\
\hline \multicolumn{7}{|l|}{ Recahan Karkas } \\
\hline Berat Dada (g/100 g karkas) & $25,12^{\mathrm{a}}$ & $26,29^{a}$ & $28,28^{a}$ & $30,15^{a}$ & $29,33^{a}$ & 2,6 \\
\hline Berat Punggung (g/100g karkas) & $26,05^{a}$ & $24,32^{\mathrm{a}}$ & $22,61^{\mathrm{a}}$ & $21,25^{\mathrm{a}}$ & $23,07^{a}$ & 2,42 \\
\hline Berat Sayap (g/100g karkas) & $15,60^{\mathrm{a}}$ & $17,44^{\mathrm{a}}$ & $15,21^{\mathrm{a}}$ & $15,54^{\mathrm{a}}$ & $15,12^{\mathrm{a}}$ & 0,99 \\
\hline Berat Paha Atas (g/100g karkas) & $16,46^{\mathrm{a}}$ & $15,55^{\mathrm{a}}$ & $15,62^{\mathrm{a}}$ & $16,31^{\mathrm{a}}$ & $15,75^{\mathrm{a}}$ & 0,95 \\
\hline Berat Paha Bawah (g/100g karkas) & $16,83^{\mathrm{a}}$ & $16,08^{a}$ & $15,21^{\mathrm{a}}$ & $16,76^{\mathrm{a}}$ & $16,72^{\mathrm{a}}$ & 0,94 \\
\hline \multicolumn{7}{|l|}{ Komposisi Fisik Karkas } \\
\hline Berat Tulang (g/100g karkas) & $35,81^{\mathrm{ab}}$ & $41,57^{a}$ & $29,00^{b}$ & $31,50^{b}$ & $35,90^{\mathrm{ab}}$ & 2,21 \\
\hline Berat Daging (g/100g karkas) & $52,75^{\mathrm{ab}}$ & $48,26^{b}$ & $57,55^{a}$ & $58,80^{\mathrm{a}}$ & $53,45^{a b}$ & 2,49 \\
\hline Berat Lemak (g/100g karkas) & $11,44^{\mathrm{ab}}$ & $10,17^{\mathrm{ab}}$ & $11,89^{a}$ & $9,70^{\mathrm{b}}$ & $10,65^{\mathrm{ab}}$ & 0,57 \\
\hline
\end{tabular}

\section{Keterangan :}

1) Perlakuan ransum kontrol tanpa penggantian tepung ikan (R0); penggantian $25 \%$ (R1); penggantian $50 \%$ (R2); penggantian $75 \%$ (R3); penggantian $100 \%$ (R4)

2) Standard Error of the Treatment Means

3) Huruf superskrip huruf yang berbeda pada baris yang sama menunjukkan perbedaan yang nyata $(P<0,05)$

10,55\%; 12,79\%; 10,89\% dan 13,30\% lebih rendah $(\mathrm{P}>0,05)$ dari perlakuan R1. Rataan persentase sayap dalam penelitian ini adalah 15,78 g/10og karkas dari rataan perlakuan pada (Tabel 3). Hasil menunjukkan tidak ada pengaruh terhadap persentase berat sayap, kemungkinan disebabkan karena ransum perlakuan iso energi dan iso protein. Menurut Rasheed et al. (1963), dengan didasarkan pada ukuran dan struktur bulu sayap, dapat diperkirakan zat-zat makanan berupa protein dan energi akan digunakan dalam jumlah besar untuk pembentukan tulang,daging dan bulu.

Persentase paha atas pada perlakuan ransum Ro menghasilkan 16,46 g/10og karkas. Perlakuan ransum R1, R2, R3 dan R4 menghasilkan persentase paha atas masing-masing 5,53\%; 5,10\%; 0,91\% dan 4,31\% lebih rendah $(\mathrm{P}>0,05)$ dibandingkan R1. Persentase paha bawah ayam buras pada perlakuan ransum Ro yaitu 16,83\% (Tabel 3). Perlakuan R1, R2, R3 dan R4 menghasilkan persentase paha bawah masing-masing 4,46\%; 9,63\%; 0,42\% dan 0,65\% lebih rendah $(\mathrm{P}>0,05)$ dari perlakuan Ro. Persentase recahan karkas paha atas dan paha bawah tidak dipengaruhi secara nyata $(\mathrm{P}>0,05)$ oleh perlakuan penggantian tepung ikan dengan susu kadaluarsa pada ransum aras penggantian. Hal ini menunjukkan bahwa distribusi nutrien untuk pembentukan komponen recahan karkas tidak berbeda pada aras penggantian tepung ikan dengan susu kadaluarsa.

Penggantian tepung ikan dengan susu kadaluarsa dalam ransum berpengaruh terhadap komposisi fisik karkas tulang, daging dan lemak subkutan termasuk kulit. Ayam buras yang mendapatkan perlakuan ransum R1 menghasilkan persentase tulang paling besar adalah 41,57 g/10og karkas. Perlakuan ransum Ro dan R4 menghasilkan persentase tulang masing-masing $13,86 \%$ dan $13,64 \%$ nyata $(\mathrm{P}<0,05)$ lebih rendah dari perlakuan R1. Perlakuan R2 dan $\mathrm{R}_{3}$ berbeda nyata $(\mathrm{P}<0,05)$ terhadap perlakuan Ro dan R4 (Tabel 3). Persentase tulang $\mathrm{R}_{3}$ rendah disebaban karena persentase daging pada perlakuan tersebut paling tinggi. Pengaruh perbedaan antar perlakuan dalam komposisi fisik tulang disebabkan karena komponen persentase tulang adalah komponen tubuh yang utama sehingga kandungan zat nutrisi dalam ransum terlebih dahulu digunakan untuk pembentukan tulang. Seperti penelitian Rasyaf (1995), pertumbuhan diawali dengan tumbuhnya jaringan tulang yang membentuk kerangka tubuh, kemudian diikuti dengan jaringan otot atau urat sebagai daging dan menyelubungi seluruh kerangka tubuh, sedangkan jaringan lemak tumbuh paling akhir. Anggara et al (2020) nutrien pada ransum terutama kandungan seart kasar akan berpengaruh terhadap komponen tulang karkas. Persentase daging ayam buras yang paling tinggi pada perlakuan R3 yaitu 58,80 g/100g karkas (Tabel 3). Perlakuan Ro dan R4 menghasilkan persentase daging masing-masing 10,29\% dan 9,10\% nyata lebih rendah $(\mathrm{P}<0,05)$ dari perlakuan $\mathrm{R}$. Hal tersebut terjadi karena berkaitan dengan bobot tulang dan lemak mendapat hasil yang lebih rendah, sehingga persentase daging yang didapatkan pada perlakuan $\mathrm{R}_{3}$ lebih tinggi. Selain itu, tingginya persentase daging berkaitan dengan kandungan serat kasar yang lebih rendah sehingga peranan nutrien bahan ransum yang berkolaborasi antara tepung ikan dengan susu kadaluarsa dapat memecah ikatan protein yang lebih kompleks menjadi protein yang mudah diserap. Sesuai dalam pendapat Wahju (2015), mengatakan bahwa protein merupakan komponen utama pembentuk urat daging. Persentase lemak ayam buras paling rendah pada perlakuan $\mathrm{R}_{3}$ yaitu 9,70 g/100g karkas. Hal tersebut disebabkan 
karena persentase daging pada perlakuan R3 paling tinggi. Selain itu, disebabkan karena kolaborasi antara tepung ikan dan susu kadaluarsa dalam ransum cukup baik dan mengandung serat kasar yang cukup tinggi, sehingga mengurangi penyerapan lemak pada usus halus.

\section{SIMPULAN}

Berdasarkan hasil penelitian dapat disimpulkan bahwa penggantian $75 \%$ tepung ikan dengan susu kadaluarsa menghasilkan berat karkas, potongan komersial, dan komposisi fisik karkas paling tinggi.

\section{UCAPAN TERIMAKASIH}

Penulis mengucapkan banyak terimakasih kepada Rektor Universitas Udayana, Fakultas Peternakan, Program Studi Magister Ilmu Peternkan atas ijin dan bantuan peminjaman alat-alat penelitian sehingga penelitian sampai penyusunan artikel ini dapat terselesaikan.

\section{DAFTAR PUSTAKA}

Alhaidary A., H.E. Mohamed and A.C. Beynen. 2010. Impact of dietary fat type and amount on growth performance and serum cholesterol in rabbits. American Journal of Animal and Veterinary Sciences 5(1): 60-64.

Alim, M.N., H.D. Sunaryo dan Wurlina. 2012. Pengaruh Pemberian Susu Afkir Terhadap Performans Ayam Pedaging Jantan. Skripsi. Fakultas Kedokteran Hewan. Universitas Airlangga. Surabaya.

Anggara, I W. B., I. B. G. Partama, dan A. A. A. S. Trisnadewi. Pengaruh pemberian sekam padi tanpa dan tanpa dengan fermentasi yang disuplementasi daun sirih dalam ransum terhadap bobot potong, non karkas ekternal, dan lemak abdominal itik Bali betina. Majalah Ilmiah Peternakan Vol. 23 No 2 Tahun 2020. P: 78-83. Sumber: https://ojs.unud. ac.id/index.php/mip/article/view/63598/36282

Anwar, S. 2011. Metode Penelitian Bisnis. Salemba Empat. Jakarta

Harper, H. A. V. W. Roodweal and P. A. 1980. Review of Physiological Chemistry. 17Ed. Lange Medical Publition. Los Altos. California.

Mufti, R. 2003. Studi ukuran dan bentuk tubuh ayam buras, ayam pelung dan ayam persilangan. Fakultas Peternakan. Institut Pertanian Bogor. Bogor.

Nita, N.S., E. Dihansih dan Anggraeni. 2015. Pengaruh pemberian kadar protein pakan yang berbeda terhadap bobot komponen karkas dan non-karkas ayam jantan petelur. Jurusan Peternakan dan Agribisnis dan Teknologi Pakan. Universitas Djuanda. Bogor

Nuriyasa I.M., I.M Mastika, I.G. Mahardika, I.W. Kasa, I.G. Ag. I Aryani. 2014. Energy and protein retention of local rabbit housed in different cages. J.Biol. Chem.Research Vol 31(2): 800 - 807.

Pertiwi, 2017. Pengaruh Penggantian Tepung Ikan dengan Susu Afkir dalam Ransum terhadap Produktivitas Ayam Buras Jantan Umur 2-10 Minggu. Tesis. Program Studi Magister Ilmu Peternakan, Fakultas Peternakan, Universitas Udayana, Bali.

Poedjiadi, A. 2006. Dasar - Dasar Biokimia. Edisi Revisi. Jakarta: UI - Press.

Pusat Data dan Informasi (Pusdatin). 2015. Perkembangan konsumsi ayam buras.Kementrian Kesehatan Republik Indonesia. Jakarta

Rasheed, A.A. F. Jeo. And A.O Mackey. 1963. Effect of clipping wings tails in chicken. Poultry Sci. 42: 1001-1009

Rasyaf, M. 1995. Pengelolaan Usaha Peternakan Ayam Pedaging. PT. Gramedia Pustaka Utama, Jakarta.

Rose, S.P. 1997. Princilpe of Poultry Science. Center of Agriculture and Bioscience International. New York

SNI. 2009. Standar Nasional Indonesia Mutu karkas dan daging ayam ICS 67.120.20 Badan Standardisasi Nasional "Hak Cipta Badan Standardisasi Nasional,

Scott, M.L., M.C. Neisheim and R.J. Young. 1982. Nutrition of The Chickens. 2nd Ed.Publishing by : M.L. Scott and Assoc. Ithaca, New York.

Steel, R.D.G, Torrie J.H. 1991. Prinsip dan Prosedur Statistika. Jakarta: PT. Gramedia.

Wahju, J. 2015 . Ilmu Nutrisi Unggas. Cetakan Ke enam, Gajah Mada University Press, Yogyakarta.

Widodo, W. 2002. Nutrisi dan Pakan Unggas Kontekstual. Malang : UniversitasMuhammadiyah Malang, Fakultas Peternakan-Perikana

Yadnya, T.G.B., I M. Nuriyasa, N. M. S. Sukmawati, A. A. A. S. Trisnadewi. 2019. Tingkat pemberian sekam padi dengan mono sodium glutamate disuplementasi effective microorganisms-4 terhadap karkas dan kualitas daging itik Campbell. Majalah Ilmiah Peternakan. Vol. 22 No 3. P: 108-112. Sumber: https://ojs.unud.ac.id/index.php/mip/article/ view/57703/33702 